\title{
ANALISIS KEMAMPUAN PEMECAHAN MASALAH MATEMATIK PESERTA DIDIK KELAS VIII SMP
}

\author{
Lusi Nuraeni $^{1}$, Huri Suhendri ${ }^{2}$, Aulia Masruroh ${ }^{3}$ \\ 1,2 Universitas Indraprasta PGRI, Jakarta \\ $\underline{\text { lusynuraeny30@gmail.com }}{ }^{1}, \underline{\text { huri unindra@yahoo.co.id }}{ }^{2}, \underline{\text { aulia.m89@gmail.com }^{3}}$
}

\begin{abstract}
This study aims to analyze students' math problem solving skills based on problem solving stages. This research uses qualitative research method. The samples in this study were grade VIII A students, the subject of the study using purposive sample techniques, involving 3 subjects representing 3 groups of problem solving abilities. Data collection using test techniques, interviews, documentation, and observation. Data analysis uses reduction, presentation, and conclusion techniques. Based on the classification of ability found from as many as 36 students obtained as many as 7 (19.44\%) "high" category, 11 students (30.56\%) including the "medium" category, and 18 students (50.00\%) "low" category. The conclusion of this study is that students' math problem solving ability in circular material is still relatively low
\end{abstract}

Keyword: Definition of problem solving, Qualitative Research

\section{Abstrak}

Penelitian ini bertujuan untuk untuk menganalisis kemampuan pemecahan masalah matematika siswa berdasarkan tahapan pemecahan masalah. Penelitian ini menggunakan metode penelitian kualitatif. Sampel dalam penelitian ini adalah siswa kelas VIII A, subjek penelitian menggunakan teknik purposive sample, melibatkan 3 subjek mewakili 3 kelompok kemampuan pemecahan masalah. Pengumpulan data menggunakan teknik tes, wawancara, dokumentasi, dan observasi. Analisis data menggunakan teknik reduksi, penyajian, dan kesimpulan. Berdasarkan klasifikasi kemampuan ditemukan dari sebanyak 36 siswa diperoleh sebanyak 7 $(19,44 \%)$ kategori "tinggi", 11 siswa (30,56\%) termasuk kategori "sedang”, dan 18 siswa (50,00\%) kategori "rendah". Kesimpulan penelitian ini bahwa kemampuan pemecahan masalah matematika siswa pada materi lingkaran masih tergolong rendah

Kata Kunci : Pemecahan Masalah, Penelitian Kualitatif 
Jurnal Lebesgue : Jurnal Ilmiah Pendidikan Matematika, Matematika dan Statistika

Lusi Nuraeni, Huri Suhendri, Aulia Masruroh

Volume 1, No. 3, Desember 2020 hal.159-171

DOI Artikel : 10.46306/lb.v1i3.34

\section{PENDAHULUAN}

Pendidikan yang bermutu saat ini merupakan suatu kebutuhan yang sangat penting dalam kehidupan manusia. Maju tidaknya suatu bangsa sangat tergantung pada pendidikan bangsa tersebut. Jika pendidikan suatu bangsa dapat menghasilkan manusia yang berkualitas lahir batin, otomatis bangsa tersebut akan maju, damai, dan tentram. Sebaliknya jika pendidikan suatu bangsa mengalami stagnasi maka bangsa itu akan terbelakang disegala bidang. Salah satu mata pelajaran yang sangat penting dalam suatu pendidikan adalah matematika. Matematika merupakan salah satu bidang studi yang menduduki peran penting dalam pendidikan, hal itu dapat dilihat dari matematika sebagai bidang studi yang dipelajari oleh semua siswa dari SD hingga SMA dan bahkan juga di Perguruan Tinggi. Menurut Amaliah (2015: 33) matematika merupakan salah satu ilmu pengetahuan yang digunakan dalam kehidupan sehari-hari baik secara umum maupun secara khusus. Secara umum matematika digunakan dalam transaksi perdagangan, pertukangan, dll. Selain sifatnya yang fleksible dan dinamis, matematika juga selalu dapat mengimbangi perkembangan zaman.

Kemampuan pemecahan masalah matematika memiliki peran penting untuk memecahkan masalah dalam kehidupan sehari-hari dan bidang lain yang relevan. Oleh karena itu pembelajaran matematika berorientasi masalah menjadi tujuan dan keterampilan yang perlu dilatihkan kepada siswa agar siswa sejak dini menjadi seorang pemecah masalah yang baik. Untuk meningkatkan kemampuan memecahkan masalah perlu dikembangkan keterampilan memahami masalah, membuat model matematika, menyelesaikan masalah, dan menafsirkan solusinya" (BSNP, 2006: 139).

Tahapan pemecahan menurut teori polya yaitu memahami masalah/membaca masalah (understand the problem/ read the problem), menyusun rencana/memilih strategi (devise a plan/select a strategy), melaksanakan rencana/memecahkan masalah (carry out a plan/ solve the problem) dan memeriksa kembali (look back) (Baiduri, 2015; Sariati, 2013).

Namun demikian kemampuan pemecahan masalah masih tergolong rendah. Hal ini terlihat dari masih banyaknya siswa yang belum dapat menerapkan tahapan pemecahan masalah, seperti memahami masalah, merencanakan, melaksanakan, dan memeriksa proses dan hasil bahkan hanya mengandalkan rumus yang praktis. Umumnya siswa menginginkan menyelesaikan yang sesingkat mungkin atau yang lebih praktis, daripada kemampuan siswa dalam memecahkan masalah pada soal yang langkah-langkahnya terurut dan sesuai prosedur dalam mengerjakan soal tersebut. Berdasarkan hasil pengumpulan data awal melalui tes, dokumentasi dan wawancara 
Jurnal Lebesgue : Jurnal Ilmiah Pendidikan Matematika, Matematika dan Statistika

Lusi Nuraeni, Huri Suhendri, Aulia Masruroh

Volume 1, No. 3, Desember 2020 hal.159-171

DOI Artikel : 10.46306/lb.v1i3.34

dengan seorang guru bidang studi matematika dan siswa kelas VIII SMPN 1 Sobang menyatakan bahwa hasil belajar matematika peserta didik masih rendah. Terlihat ketika dilakukan tes uraian kepada siswa yang mendapatkan nilai tinggi masih kurang dan yang mendapatkan nilai rendah sebanyak 50\%. Kedua ketika proses wawancara dengan siswa mengenai hasil jawaban siswa banyak siswa yang menjawab soal tersebut kurang tepat dan tidak sesuai dengan langkah langkah penyelesaian masalah matematika.

Dari permasalahan diatas, maka tujuan penelitian ini adalah untuk menganalisis kemampuan pemecahan masalah matematika berdasarkan tahapan pemecahan masalah matematika..

\section{METODE PENELITIAN}

Penelitian dilakukan di kelas VIII A di SMP Negeri 1 Sobang. Jenis penelitian ini adalah penelitian deskriptif analitis. Deskriptif analitis merupakan metode yang bertujuan mendeskripsikan atau memberi gambaran terhadap suatu objek penelitian yang diteliti melalui sampel atau data yang telah terkumpul dan membuat kesimpulan yang berlaku umum.

Pengumpulan data menggunakan teknik observasi, wawancara, studi Literatur. Sedangkan teknik analisis data menggunakan teknik pengelompokan data, pengelolaan data, analisis data dan kesimpulan. Diagram pengumpulan dan analisis data disajikan pada Gambar 1.

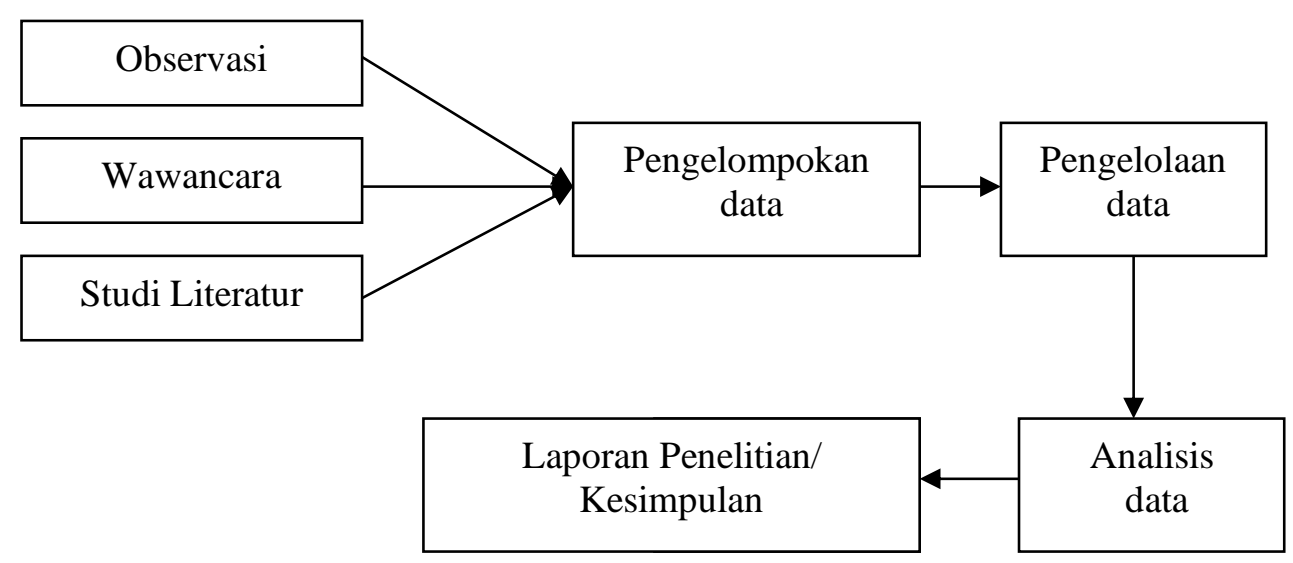

\section{Gambar 1. Diagram Teknik Pengumpulan dan Analisis Data}

Instrumen penelitian menggunakan tes, pedoman wawancara, dan dokumentasi. Instrumen tes berbentuk tes uraian sebanyak 10 soal untuk menjaring data kemampuan pemecahan masalah matematika. 
Jurnal Lebesgue : Jurnal Ilmiah Pendidikan Matematika, Matematika dan Statistika

Lusi Nuraeni, Huri Suhendri, Aulia Masruroh

Volume 1, No. 3, Desember 2020 hal.159-171

DOI Artikel : 10.46306/lb.v1i3.34

\section{HASIL DAN PEMBAHASAN}

Berdasarkan data dari sumber RPP yang digunakan oleh guru mata pelajaran matematika dalam materi lingkaran, maka dapat dilihat bahwa RPP tersebut dibuat dalam sembilan pertemuan. Sumber belajar dari RPP ini menggunakan buku matematika kelas VIII semester 2 kurikulum 2013 revisi 2017. Selain itu metode pembelajaran yang digunakan adalah mengorientasi siswa terhadap masalah, Mengorganisasikan peserta didik, Membimbing penyelidikan individual dan kelompok, Mengembangkan dan menyajikan hasil karya, Menganalisa dan mengevaluasi proses pemecahan masalah. Metode pembelajaran ini berhubungan dengan model pembelajaran yang dipakai karena dalam RPP ini model pembelajaran yang dipakai adalah model Problem Based Learning.

Berdasarkan hasil tes analisis kemampuan pemecahan masalah kepada peserta didik kelas VIII A yang berjumlah 36 siswa di SMP Negeri 1 Sobang Kabupaten Lebak diperoleh nilai rata - rata dari seluruh siswa yaitu 66. Kkm mata pelajaran matematika kelas VIII adalah 75. Maka dari itu berdasarkan nilai rata - rata keseluruhan siswa masih banyak yang belum mencapai kkm yang telah ditentukan oleh sekolah. Data nilai siswa dapat di lihat pada tabel 1 berikut.

\section{Tabel 1}

Data Nilai Siswa Kelas VIII A SMP Negeri 1 Sobang

\begin{tabular}{cccccccccccc}
\hline \multirow{2}{*}{ Resp } & \multicolumn{10}{c}{ No Soal } & Skor \\
& $\mathbf{8}$ & $\mathbf{8}$ & $\mathbf{9}$ & $\mathbf{1 2}$ & $\mathbf{1 2}$ & $\mathbf{1 0}$ & $\mathbf{1 2}$ & $\mathbf{1 0}$ & $\mathbf{9}$ & $\mathbf{1 0}$ & Total \\
\hline 1 & 8 & 8 & 8 & 10 & 8 & 9 & 8 & 8 & 8 & 8 & 83 \\
\hline 2 & 6 & 6 & 5 & 6 & 6 & 6 & 6 & 7 & 6 & 6 & 60 \\
\hline 3 & 6 & 8 & 7 & 6 & 6 & 7 & 6 & 6 & 7 & 8 & 67 \\
\hline 4 & 8 & 8 & 8 & 8 & 9 & 8 & 8 & 10 & 8 & 8 & 83 \\
\hline 5 & 8 & 8 & 8 & 7 & 8 & 9 & 8 & 8 & 8 & 8 & 80 \\
\hline 6 & 5 & 6 & 5 & 6 & 5 & 7 & 6 & 6 & 8 & 6 & 60 \\
\hline 7 & 6 & 6 & 6 & 8 & 8 & 8 & 6 & 10 & 6 & 6 & 70 \\
\hline 8 & 6 & 6 & 5 & 6 & 9 & 6 & 6 & 7 & 6 & 6 & 63 \\
\hline 9 & 8 & 8 & 9 & 10 & 8 & 8 & 8 & 8 & 8 & 8 & 83 \\
\hline 10 & 6 & 6 & 5 & 5 & 6 & 5 & 6 & 7 & 5 & 6 & 57 \\
\hline 11 & 5 & 6 & 5 & 6 & 6 & 6 & 6 & 7 & 5 & 5 & 57 \\
\hline 12 & 6 & 6 & 5 & 6 & 7 & 6 & 6 & 7 & 8 & 6 & 63 \\
\hline 13 & 6 & 5 & 5 & 6 & 6 & 5 & 6 & 6 & 9 & 6 & 60 \\
\hline 14 & 7 & 8 & 7 & 7 & 10 & 9 & 8 & 8 & 8 & 8 & 80 \\
\hline 15 & 8 & 8 & 6 & 6 & 6 & 7 & 6 & 6 & 7 & 7 & 67 \\
\hline 16 & 5 & 7 & 6 & 5 & 5 & 6 & 6 & 7 & 5 & 5 & 57 \\
\hline 17 & 5 & 5 & 5 & 6 & 5 & 7 & 6 & 8 & 7 & 6 & 60 \\
\hline
\end{tabular}




\begin{tabular}{cccccccccccc}
\hline \multirow{2}{*}{ Resp } & \multicolumn{10}{c}{ No Soal } & Skor \\
& $\mathbf{8}$ & $\mathbf{8}$ & $\mathbf{9}$ & $\mathbf{1 2}$ & $\mathbf{1 2}$ & $\mathbf{1 0}$ & $\mathbf{1 2}$ & $\mathbf{1 0}$ & $\mathbf{9}$ & $\mathbf{1 0}$ & Total \\
\hline 18 & 5 & 5 & 5 & 6 & 8 & 5 & 6 & 7 & 5 & 5 & 57 \\
\hline 19 & 7 & 5 & 5 & 5 & 6 & 5 & 6 & 6 & 9 & 6 & 60 \\
\hline 20 & 8 & 8 & 6 & 6 & 6 & 6 & 6 & 6 & 8 & 7 & 67 \\
\hline 21 & 7 & 8 & 6 & 6 & 6 & 6 & 7 & 6 & 8 & 7 & 67 \\
\hline 22 & 5 & 6 & 5 & 6 & 6 & 5 & 5 & 5 & 7 & 7 & 57 \\
\hline 23 & 7 & 8 & 8 & 6 & 6 & 6 & 7 & 7 & 8 & 7 & 70 \\
\hline 24 & 7 & 7 & 6 & 5 & 5 & 6 & 6 & 6 & 6 & 6 & 60 \\
\hline 25 & 7 & 8 & 7 & 7 & 8 & 9 & 10 & 8 & 8 & 8 & 80 \\
\hline 26 & 6 & 6 & 5 & 6 & 5 & 5 & 5 & 7 & 5 & 7 & 57 \\
\hline 27 & 6 & 6 & 5 & 6 & 5 & 6 & 7 & 6 & 8 & 8 & 63 \\
\hline 28 & 8 & 7 & 6 & 6 & 6 & 6 & 6 & 6 & 8 & 8 & 67 \\
\hline 29 & 8 & 8 & 9 & 9 & 10 & 9 & 8 & 8 & 9 & 9 & 87 \\
\hline 30 & 7 & 6 & 6 & 5 & 6 & 5 & 6 & 6 & 6 & 7 & 60 \\
\hline 31 & 5 & 6 & 6 & 6 & 5 & 5 & 7 & 5 & 5 & 7 & 57 \\
\hline 32 & 7 & 8 & 6 & 8 & 6 & 6 & 8 & 7 & 7 & 7 & 70 \\
\hline 33 & 7 & 8 & 6 & 6 & 6 & 8 & 7 & 7 & 7 & 8 & 70 \\
\hline 34 & 5 & 6 & 5 & 5 & 5 & 5 & 7 & 7 & 5 & 7 & 57 \\
\hline 35 & 6 & 8 & 6 & 6 & 8 & 6 & 6 & 6 & 7 & 8 & 67 \\
\hline 36 & 8 & 7 & 6 & 6 & 8 & 6 & 6 & 6 & 6 & 8 & 67 \\
\hline
\end{tabular}

Deskripsi kemampuan pemecahan masalah matematis siswa diperoleh berdasarkan hasil tes kemampuan pemecahan masalah dan wawancara. Tes kemampuan pemecahan masalah berupa 10 soal berbentuk uraian dengan materi lingkaran. Tes kemampuan pemecahan masalah dilaksanakan pada tanggal 17 Mei 2020. Tes kemampuan pemecahan masalah dikerjakan oleh siswa secara individu dan jujur. Setelah dilakukan tes kemampuan pemecahan masalah, peneliti menganalisis kemampuan pemecahan masalah siswa. Berdasarkan indikator-indikator tahapan kemampuan pemecahan masalah, peneliti membuat pedoman penskoran untuk mengklasifikasikan kemampuan pemecahan masalah siswa. Tingkat kemampuan pemecahan masalah siswa dapat dilihat pada tabel 2 berikut:

Tabel 2

Tingkat Kemampuan Pemecahan Masalah Siswa

\begin{tabular}{|c|c|c|c|c|}
\hline No & Nilai & Kelompok & $\begin{array}{c}\text { Jumlah } \\
\text { Siswa }\end{array}$ & $\begin{array}{c}\text { Persentase } \\
(\%)\end{array}$ \\
\hline
\end{tabular}




\begin{tabular}{|c|c|c|c|c|}
\hline 1. & $80,0-100$ & Tinggi & 7 & 19,44 \\
\hline 2. & $65-79,9$ & Sedang & 11 & 30,56 \\
\hline 3. & $55-64,9$ & Rendah & 18 & 50,00 \\
\hline \multicolumn{3}{|c|}{ JUMLAH } & 36 & 100 \\
\hline
\end{tabular}

Berdasarkan tabel diatas dapat dilihat bahwa tingkat kemampuan pemecahan masalah siswa adalah: jumlah siswa yang memperoleh nilai pada interval 80-100 atau yang memenuhi kriteria tinggi adalah sebanyak 7 orang siswa atau sebesar 19,44 \%, yang memperoleh nilai pada interval 65-79,9 atau yang memenuhi kriteria sedang adalah sebanyak 11 orang siswa atau sebesar 30,56 \% , yang memperoleh nilai pada interval 55-64,9 atau yang termasuk kriteria rendah adalah sebanyak 18 orang siswa atau sebesar 50,00\%.

Perlu dilakukan analisis secara mendalam untuk mengetahui kemampuan pemecahan masalah siswa. Dilakukan dua kali analisis untuk mengetahui kemampuan pemecahan masalah siswa yaitu dengan menganalisis hasil tes tertulis dan melakukan wawancara yang mendalam kepada subjek yang dipilih melalui beberapa pertimbangan untuk mewakili setiap kriteria kemampuan pemecahan masalah yaitu kriteria tinggi, sedang, dan rendah.

Berdasarkan data nilai siswa dari 36 siswa terdapat 7 siswa yang memperoleh nilai pada interval 80-100 atau yang memenuhi kriteria tinggi. Kelompok siswa yang memenuhi kriteria tinggi dapat dilihat pada tabel 3 berikut.

\section{Tabel 3}

Kelompok Siswa yang Memenuhi Kriteri Tinggi

\begin{tabular}{cccccccccccc}
\hline & \multicolumn{10}{c}{ No Soal } & \multicolumn{1}{c}{ Skor } \\
\cline { 2 - 11 } Resp & $\mathbf{1}$ & $\mathbf{2}$ & $\mathbf{3}$ & $\mathbf{4}$ & $\mathbf{5}$ & $\mathbf{6}$ & $\mathbf{7}$ & $\mathbf{8}$ & $\mathbf{9}$ & $\mathbf{1 0}$ & Total \\
\cline { 2 - 10 } & $\mathbf{8}$ & $\mathbf{8}$ & $\mathbf{9}$ & $\mathbf{1 2}$ & $\mathbf{1 2}$ & $\mathbf{1 0}$ & $\mathbf{1 2}$ & $\mathbf{1 0}$ & $\mathbf{9}$ & $\mathbf{1 0}$ & \\
\hline 1 & 8 & 8 & 8 & 10 & 8 & 9 & 8 & 8 & 8 & 8 & 83 \\
\hline 4 & 8 & 8 & 8 & 8 & 9 & 8 & 8 & 10 & 8 & 8 & 83 \\
\hline 5 & 8 & 8 & 8 & 7 & 8 & 9 & 8 & 8 & 8 & 8 & 80 \\
\hline 9 & 8 & 8 & 9 & 10 & 8 & 8 & 8 & 8 & 8 & 8 & 83 \\
\hline 14 & 7 & 8 & 7 & 7 & 10 & 9 & 8 & 8 & 8 & 8 & 80 \\
\hline 25 & 7 & 8 & 7 & 7 & 8 & 9 & 10 & 8 & 8 & 8 & 80 \\
\hline 29 & 8 & 8 & 9 & 9 & 10 & 9 & 8 & 8 & 9 & 9 & 87 \\
\hline
\end{tabular}

Berdasarkan tabel kelompok siswa yang mempeoleh kriteria tinggi, S-29 dipilih untuk 
Jurnal Lebesgue : Jurnal Ilmiah Pendidikan Matematika, Matematika dan Statistika

Lusi Nuraeni, Huri Suhendri, Aulia Masruroh

Volume 1, No. 3, Desember 2020 hal.159-171

DOI Artikel : 10.46306/lb.v1i3.34

mewakili 7 orang siswa yang memiliki kemampuan pemecahan masalah pada kelompok tinggi. Hasil tes tertulis kemampuan pemecahan masalah yang telah dikerjakan menunjukkan hasil yang baik.

Berdasarkan data nilai siswa dari 36 siswa terdapat 11 siswa yang memperoleh nilai pada interval 65-79,9 atau yang memenuhi kriteria sedang. Kelompok siswa yang memenuhi kriteria sedang dapat dilihat pada tabel 4 berikut.

\section{Tabel 4}

\section{Kelompok Siswa yang Memenuhi Kriteria Sedang}

\begin{tabular}{cccccccccccc}
\hline & \multicolumn{10}{c}{ No Soal } & \multicolumn{1}{c}{ Sesp } \\
\cline { 2 - 9 } & $\mathbf{1}$ & $\mathbf{2}$ & $\mathbf{3}$ & $\mathbf{4}$ & $\mathbf{5}$ & $\mathbf{6}$ & $\mathbf{7}$ & $\mathbf{8}$ & $\mathbf{9}$ & $\mathbf{1 0}$ & $\begin{array}{c}\text { Skor } \\
\text { Total }\end{array}$ \\
\cline { 2 - 9 } & $\mathbf{8}$ & $\mathbf{8}$ & $\mathbf{9}$ & $\mathbf{1 2}$ & $\mathbf{1 2}$ & $\mathbf{1 0}$ & $\mathbf{1 2}$ & $\mathbf{1 0}$ & $\mathbf{9}$ & $\mathbf{1 0}$ & \\
\hline 3 & 6 & 8 & 7 & 6 & 6 & 7 & 6 & 6 & 7 & 8 & 67 \\
\hline 7 & 6 & 6 & 6 & 8 & 8 & 8 & 6 & 10 & 6 & 6 & 70 \\
\hline 15 & 8 & 8 & 6 & 6 & 6 & 7 & 6 & 6 & 7 & 7 & 67 \\
\hline 20 & 8 & 8 & 6 & 6 & 6 & 6 & 6 & 6 & 8 & 7 & 67 \\
\hline 21 & 7 & 8 & 6 & 6 & 6 & 6 & 7 & 6 & 8 & 7 & 67 \\
\hline 23 & 7 & 8 & 8 & 6 & 6 & 6 & 7 & 7 & 8 & 7 & 70 \\
\hline 28 & 8 & 7 & 6 & 6 & 6 & 6 & 6 & 6 & 8 & 8 & 67 \\
\hline 32 & 7 & 8 & 6 & 8 & 6 & 6 & 8 & 7 & 7 & 7 & 70 \\
\hline 33 & 7 & 8 & 6 & 6 & 6 & 8 & 7 & 7 & 7 & 8 & 70 \\
\hline 35 & 6 & 8 & 6 & 6 & 8 & 6 & 6 & 6 & 7 & 8 & 67 \\
\hline 36 & 8 & 7 & 6 & 6 & 8 & 6 & 6 & 6 & 6 & 8 & 67 \\
\hline
\end{tabular}

Berdasarkan tabel kelompok siswa yang mempeoleh kriteria sedang, S-23 dipilih untuk mewakili 11 orang siswa yang memiliki kemampuan pemecahan masalah pada kelompok sedang. Hasil tes tertulis kemampuan pemecahan masalah yang telah dikerjakan menunjukkan hasil yang baik.

Sebanyak 50,00\% atau 18 orang siswa memiliki kemampuan pemecahan masalah yang termasuk dalam kelompok "rendah". Kelompok siswa yang memenuhi kriteria rendah dapat dilihat pada tabel 5 berikut.

Tabel 5

Kelompok Siswa yang Memenuhi Kriteria Rendah

\begin{tabular}{llllllllllll}
\hline \multirow{2}{*}{$\operatorname{Resp}$} & $\mathbf{1}$ & $\mathbf{2}$ & $\mathbf{3}$ & $\mathbf{4}$ & $\mathbf{5}$ & $\mathbf{6}$ & $\mathbf{7}$ & $\mathbf{8}$ & $\mathbf{9}$ & $\mathbf{1 0}$ & Skor \\
\cline { 2 - 5 } & Total
\end{tabular}




\begin{tabular}{cccccccccccc}
\hline & $\mathbf{8}$ & $\mathbf{8}$ & $\mathbf{9}$ & $\mathbf{1 2}$ & $\mathbf{1 2}$ & $\mathbf{1 0}$ & $\mathbf{1 2}$ & $\mathbf{1 0}$ & $\mathbf{9}$ & $\mathbf{1 0}$ & \\
\hline 2. & 6 & 6 & 5 & 6 & 6 & 6 & 6 & 7 & 6 & 6 & 60 \\
\hline 6. & 5 & 6 & 5 & 6 & 5 & 7 & 6 & 6 & 8 & 6 & 60 \\
\hline 8. & 6 & 6 & 5 & 6 & 9 & 6 & 6 & 7 & 6 & 6 & 63 \\
\hline 10. & 6 & 6 & 5 & 5 & 6 & 5 & 6 & 7 & 5 & 6 & 57 \\
\hline 11. & 5 & 6 & 5 & 6 & 6 & 6 & 6 & 7 & 5 & 5 & 57 \\
\hline 12. & 6 & 6 & 5 & 6 & 7 & 6 & 6 & 7 & 8 & 6 & 63 \\
\hline 13. & 6 & 5 & 5 & 6 & 6 & 5 & 6 & 6 & 9 & 6 & 60 \\
\hline 16. & 5 & 7 & 6 & 5 & 5 & 6 & 6 & 7 & 5 & 5 & 57 \\
\hline 17. & 5 & 5 & 5 & 6 & 5 & 7 & 6 & 8 & 7 & 6 & 60 \\
\hline 18. & 5 & 5 & 5 & 6 & 8 & 5 & 6 & 7 & 5 & 5 & 57 \\
\hline 19. & 7 & 5 & 5 & 5 & 6 & 5 & 6 & 6 & 9 & 6 & 60 \\
\hline 22. & 5 & 6 & 5 & 6 & 6 & 5 & 5 & 5 & 7 & 7 & 57 \\
\hline 24. & 7 & 7 & 6 & 5 & 5 & 6 & 6 & 6 & 6 & 6 & 60 \\
\hline 26. & 6 & 6 & 5 & 6 & 5 & 5 & 5 & 7 & 5 & 7 & 57 \\
\hline 27. & 6 & 6 & 5 & 6 & 5 & 6 & 7 & 6 & 8 & 8 & 63 \\
\hline 30. & 7 & 6 & 6 & 5 & 6 & 5 & 6 & 6 & 6 & 7 & 60 \\
\hline 31. & 5 & 6 & 6 & 6 & 5 & 5 & 7 & 5 & 5 & 7 & 57 \\
\hline 34. & 5 & 6 & 5 & 5 & 5 & 5 & 7 & 7 & 5 & 7 & 57 \\
\hline & & & & & & & & & &
\end{tabular}

Siswa dengan kode S-10 dipilih untuk menjadi subjek yang akan dianalisis dan diwawancari mewakili 18 orang siswa yang memiliki kemampuan pemecahan masalah pada kelompok rendah. Hasil tes tertulis kemampuan pemecahan masalah yang telah dikerjakan menunjukkan hasil yang cukup baik.

Pemecahan masalah matematis merupakan pemecahan masalah yang memerlukan tahap-tahap atau langkah-langkah yang dilakukan siswa secara sistematis. Tingkat pemecahan masalah matematika siswa kelas VIII SMP di disatuan pendidikan masih rendah. Menurut Suratmi (2017) kemampuan pemecahan masalah yang harus dimiliki siswa adalah bagaimana cara mengatasi permasalahan yang berhubungan dengan kegiatan belajarnya, antara lain pemecahan masalah pada soal matematika. Pemecahan masalah dapat dikatakan sebagai suatu metode pembelajaran yang dapat melatih dan menunjang kemampuan pemecahan masalah pada soal matematika dalam kegiatan pembelajaran. Masalah dalam kegiatan pembelajaran tersebut dapat datang dari guru, suatu fenomena atau persoalan sehari-hari yang dijumpai siswa.

Selain itu menurut Arigiyati \& Istiqomah (2016). Pemecahan masalah sangat penting dalam matematika, karena pemecahan masalah merupakan hal pokok dalam meningkatkan kemampuan berfikir tingkat tinggi siswa, guna untuk mengeksplorasi pengetahuan dan 
Jurnal Lebesgue : Jurnal Ilmiah Pendidikan Matematika, Matematika dan Statistika

Lusi Nuraeni, Huri Suhendri, Aulia Masruroh

Volume 1, No. 3, Desember 2020 hal.159-171

DOI Artikel : 10.46306/lb.v1i3.34

keterampilan yang sudah dimiliki untuk menyelesaikan masalah yang jarang siswa temui. Maka perlu adanya faktor - faktor yang dapat mempengaruhi tingkat pemecahan masalah matematika tersebut sehingga proses pembelajaran di dalam kelas akan efektif dan berjalan sesuai dengan rencana.

Menurut (Irawan, Suharta, \& Suparta, 2016) terdapat beberapa faktor yang mempengaruhi kemampuan pemecahan masalah matematika siswa terutama faktor internal seperti kemampuan pengetahuan awal, apresiasi matematika, dan kecerdasan logis matematis. apresiasi matematika dan kecerdasan logis matematis. Pada masing-masing siswa memiliki apresiasi yang berbeda-beda terhadap matematika. Perbedaan apresiasi ini akan berkaitan pada keterlibatan siswa dalam proses pembelajaran di kelas. Selain itu faktor kecerdasan logis matematis juga perlu diperhatikan. Anak seperti ini memiliki kemampuan yang baik dalam mencari hubungan antar informasi yang diperoleh dari masalah yang mereka temui. Hal ini sejalan dengan langkah- langkah pemecahan masalah yaitu pada langkah memahami masalah dan merencanakan penyelesaian.

Berdasarkana penjelasan diatas dapat disimpulkan bahwa pemecahan masalah matematika adalah suatu keharusan yang dimiliki oleh seorang siswa tentunya harus dibantu oleh para pendidik yang mengajar di dalam suatu kelas tersebut dengan melihat beberapa faktor misalnya adalah kemampuan pengetahuan awal, apresiasi matematika, dan kecerdasan logis matematis. Selain itu masih banyak lagi fakto - faktor yang mempengaruhi pemecahan masalah matematika.

Berdasarkan hasil analisis data kemampuan pemecahan masalah siswa pada materi lingkaran diperoleh hasil tes kemampuan pemecahan masalah yang dikelompokkan ke dalam tiga kelompok yaitu kelompok tinggi, sedang, dan rendah. Pembahasan mengenai hasil analisis akan diuraikan berdasarkan kelompok kemampuan pemecahan masalah siswa sebagai berikut:

\section{Kemampuan Pemecahan Masalah pada Kelompok Tinggi}

Dengan membandingkan lembar jawaban subjek dan transkip wawancara maka dideskripsikan bahwa: (1) pada indikator memahami masalah subjek telah mampu memahami masalah dengan baik, terlihat dari lembar jawaban subjek yang menuliskan apa yang diketahui dan ditanya dengan benar serta mampu menjelaskan masalah pada soal dengan kalimat sendiri. (2) Pada indikator merencanakan penyelesaian subjek dapat memahami keterkaitan antara apa yang diketahui dan ditanyakan, membuat langkah-langkah penyelesaian yang sesuai dengan masalah, menentukan rumus yang akan digunakan, mencari subtujuan dan 
Jurnal Lebesgue : Jurnal Ilmiah Pendidikan Matematika, Matematika dan Statistika

Lusi Nuraeni, Huri Suhendri, Aulia Masruroh

Volume 1, No. 3, Desember 2020 hal.159-171

DOI Artikel : 10.46306/lb.v1i3.34

mengurutkan informasi yang ada pada soal dan dapat menyederhanakan masalah dengan cara menentukan langkah penyelesaian sesuai dengan soal dan yang di tanyakan, hal itu juga terlihat pada lembar jawaban tes kemampuan pemecahan masalah subjek dan mengerjakannya sesuai dengan urutan informasi. (3) Pada indikator melaksanakan rencana penyelesaian, subjek dapat melaksanakan rencana dengan benar sesuai dengan langkah-langkah yang telah disusun sebelumnya. (4) Pada indikator memeriksa kembali, dan subjek melakukan pemeriksaan dengan memastikan jawaban yang telah dibuat.

2. Kemampuan Masalah Siswa pada Kelompok Sedang

Berdasarkan analisis yang telah dilakukan pada subjek yang mewakili kemampuan pemecahan masalah siswa pada kategori "baik" dan membandingkan jawaban subjek dan transkip wawancara maka dideskripsikan bahwa: (1) pada indicator memahami masalah subjek telah mampu memahami masalah, terlihat dari lembar jawaban subjek yang menuliskan apa yang diketahui dari soal, namun tidak menuliskan apa yang ditanya di lembar jawaban tes kemampuan pemecahan masalah serta subjek mampu menjelaskan masalah pada soal dengan kalimat sendiri. (2) Pada indikator merencanakan penyelesaian subjek memahami keterkaitan antara apa yang diketahui dan ditanyakan, membuat langkah-langkah penyelesaian yang sesuai dengan masalah, menentukan rumus yang akan digunakan, mencari subtujuan dan mengurutkan informasi yang ada pada soal dan dapat menyederhanakan masalah dengan cara menentukan langkah penyelesaian namun terdapat beberapa kekeliruan dalam perhitungan hal itu terlihat pada lembar jawaban tes kemampuan pemecahan masalah subjek dan subjek telah mengerjakannya sesuai dengan urutan informasi. (3) Pada indikator melaksanakan rencana penyelesaian, subjek dapat melaksanakan rencana dengan benar sesuai dengan langkah-langkah yang telah disusun sebelumnya, namun subjek melakukan beberapa kekeliruan dalam perhitungan seperti yang terlihat pada lembar jawaban subjek, namun tetap mendapatkan jumlah uang dengan tepat sesuai dengan yang ditanyakan dalam soal. (4) Pada indikator memeriksa kembali, subjek tidak melakukan pemeriksaan dengan memastikan jawaban yang telah dibuat, subjek menunjukkan pertimbangan yang logis dalam menentukan jawaban.

3. Kemampuan Pemecahan Masalah Siswa pada Kelompok Rendah

Setelah dilakukan analisis pada Subjek yang mewakili kategori cukup maka dideskripsikan untuk kemampuan pemecahan masalah siswa pada kategori "cukup" bahwa: (1) pada indikator memahami masalah subjek telah mampu memahami masalah, terlihat dari 
Jurnal Lebesgue : Jurnal Ilmiah Pendidikan Matematika, Matematika dan Statistika

Lusi Nuraeni, Huri Suhendri, Aulia Masruroh

Volume 1, No. 3, Desember 2020 hal.159-171

DOI Artikel : 10.46306/lb.v1i3.34

lembar jawaban subjek yang menuliskan apa yang diketahui, namun tidak menuliskan apa yang ditanya di lembar jawaban tes kemampuan pemecahan masalah serta mampu menjelaskan masalah pada soal dengan kalimat sendiri. (2) Pada indikator merencanakan penyelesaian subjek mampu membuat rencana penyelesaian masalah sesuai prosedur dan mengarah pada solusi yang benar dan sesuai dengan masalah, mengurutkan informasi yang ada pada soal, dan dapat menyederhanakan masalah namun terdapat beberapa kekeliruan dalam perhitungan hal itu terlihat pada lembar jawaban tes kemampuan pemecahan masalah subjek. Subjek telah mampu menyelesaikan masalah sesuai dengan urutan informasi. (3) Pada indikator melaksanakan rencana penyelesaian, subjek dapat melaksanakan prosedur yang benar dan mungkin menghasilkan jawaban benar tapi salah dalam perhitungan dan subjek mampu melaksanakan rencana dengan benar sesuai dengan langkah-langkah yang telah disusun sebelumnya, namun subjek melakukan beberapa kekeliruan dalam perhitungan seperti yang terlihat pada lembar jawaban subjek. (4) Pada indikator memeriksa kembali, tidak ada pemeriksaan atau tidak ada keterangan lain untuk membuktikan jawaban, subjek tidak melakukan pemeriksaan dengan memastikan jawaban melalui persamaan yang disusun, dan tidak menunjukkan adanya pertimbangan yang logis dalam menentukan jawaban.

\section{KESIMPULAN}

Kemampuan pemecahan masalah siswa kelas VIII A SMPN 1 Sobang Kabupaten Lebak diberikan suatu tes menunjukkan dari sebanyak 36 orang siswa diperoleh sebanyak 7 orang siswa atau 19,44\% memiliki kemampuan pemecahan masalah yang termasuk dalam kelompok "tinggi", 11 orang siswa atau 30,56\% termasuk kedalam kelompok "sedang", dan 18 orang siswa atau sebanyak 50,00\% termasuk kedalam kelompok "rendah".

Berdasarkan hasil penelitian diperoleh persentase tingkat kemampuan pemecahan masalah siswa dari yang terbesar hingga yang terkecil adalah kelompok terkecil adalah kelompok tinggi $(19,44 \%)$, kedua kelompok sedang (30,56\%), dan yang terbesar adalah kelompok rendah adalah $(50,00 \%)$.

Kemampuan siswa pada tiap tahapan dalam setiap kelompok diperoleh beberapa kesimpulan sebagai berikut:

a. Kemampuan Pemecahan Masalah pada Kelompok Tinggi

1) pada indikator memahami masalah: siswa mampu memahami masalah dengan baik, subjek yang menuliskan apa yang diketahui dan ditanya dengan benar serta mampu menjelaskan masalah pada soal dengan kalimat sendiri. 
2) Pada indikator merencanakan penyelesaian: siswa dapat memahami keterkaitan antara apa yang diketahui dan ditanyakan, membuat langkah-langkah penyelesaian yang sesuai dengan masalah, menentukan rumus yang akan digunakan, mencari subtujuan dan mengurutkan informasi yang ada pada soal dan dapat menyederhanakan.

3) Pada indikator melaksanakan rencana penyelesaian: siswa dapat melaksanakan rencana dengan benar sesuai dengan langkah-langkah yang telah disusun sebelumnya.

4) Pada indikator memeriksa kembali: siswa melakukan pemeriksaan dengan memastikan jawaban melalui persamaan yang disusun

b. Kemampuan Masalah Siswa pada Kelompok Sedang

1) pada indikator memahami masalah: siswa mampu memahami masalah, siswa menuliskan apa yang diketahui dari soal, serta siswa mampu menjelaskan masalah dengan kalimat sendiri.

2) Pada indikator merencanakan penyelesaian: siswa mampu memahami keterkaitan antara apa yang diketahui dan ditanyakan, membuat langkah-langkah penyelesaian yang sesuai dengan masalah, menentukan rumus yang akan digunakan, mencari subtujuan dan mengurutkan informasi yang ada pada soal dan dapat menyederhanakan, siswa telah mengerjakannya sesuai dengan urutan informasi.

3) Pada indikator melaksanakan rencana penyelesaian: siswa dapat melaksanakan rencana dengan benar sesuai dengan langkah-langkah yang telah disusun sebelumnya.

4) Pada indikator memeriksa kembali: siswa tidak melakukan pemeriksaan dengan memastikan jawaban melalui persamaan yang disusun.

c. Kemampuan Pemecahan Masalah Siswa pada Kelompok Rendah

1) pada indikator memahami masalah: siswa mampu memahami masalah dan menuliskan apa yang diketahui, serta mampu menjelaskan masalah pada soal dengan kalimat sendiri.

2) Pada indikator merencanakan penyelesaian: siswa mampu membuat rencana penyelesaian masalah sesuai prosedur dan mengarah pada solusi yang benar namun terdapat beberapa kekeliruan dalam perhitungan, siswa telah mampu menyelesaikan masalah sesuai dengan urutan informasi.

3) Pada indikator melaksanakan rencana penyelesaian: siswa dapat melaksanakan prosedur yang benar dan mungkin menghasilkan jawaban benar tapi salah dalam perhitungan dan siswa mampu melaksanakan rencana dengan benar namun subjek 
melakukan beberapa kekeliruan dalam perhitungan.

4) Pada indikator memeriksa kembali: siswa tidak melakukan pemeriksaan atau tidak ada keterangan lain untuk membuktikan jawaban, dan tidak menunjukkan adanya pertimbangan yang logis dalam menentukan jawaban.

\section{DAFTAR PUSTAKA}

Amaliah, Nur. 2015. Pengaruh Teknik Pembelajaran dan Kreatifitas Belajar Siswa terhadap Hasil Belajar Matematika. Jurnal JKPM Universitas Indraprasta PGRI Jakarta. Vol.1, No.01 hal.33.

Arigiyati, T. A., \& Istiqomah, I. (2016). Perbedaan Kemampuan Pemecahan Masalah dengan Pembelajaran Learning Cycle dan Konvensional Pada Mahasiswa Prodi Pendidikan Matematika FKIP UST. Union: Jurnal Ilmiah Pendidikan Matematika, 4(1).

Irawan, I. P. E., Suharta, I. G. P., \& Suparta, I. N. (2016). Faktor-Faktor Yang Mempengaruhi Kemampuan Pemecahan Masalah Matematika. Jurnal Pendidikan. Vol (8). Hal: 69-73.

Suratmi, S., \& Purnami, A. S. (2017). Pengaruh Strategi Metakognitif Terhadap Kemampuan Pemecahan Masalah Matematika Ditinjau dari Persepsi siswa Terhadap Pelajaran Matematika. UNION.: Jurnal Ilmiah Pendidikan Matematika, 5(2). 